DOI: https://doi.org/10.47405/mjssh.v6i10.1062

\begin{tabular}{|c|c|}
\hline & Malaysian Journal of Social Sciences and Humanities (MJSSH) \\
\hline Malaysian Journal of & Volume 6, Issue 10, October 2021 \\
\hline 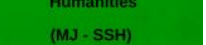 & e-ISSN : 2504-8562 \\
\hline & $\begin{array}{l}\text { Journal home page: } \\
\text { www.msocialsciences.com }\end{array}$ \\
\hline
\end{tabular}

\title{
Pengaruh Pendekatan Mass Lecture dan Motivasi Terhadap Kepuasan Pembelajaran Bahasa Arab Komunikasi
}

\author{
Ibrahim Abdullah', Asma' Ammar', Muhamad Zaidi Zakaria1, Muhammad Arsyad Abdul Majid1, \\ Abdul Azim Muhamad Isa ${ }^{1}$ \\ 1Jabatan Bahasa Asia dan Eropah, Akademi Pengajian Bahasa, Universiti Teknologi MARA Shah Alam, Malaysia
}

Correspondence: Ibrahim Abdullah (ibrahim970@uitm.edu.my)

\begin{abstract}
Abstrak
Sebagai pelanggan pendidikan, kepuasan pelajar dalam pembelajaran Bahasa Arab Komunikasi sangat penting dalam proses pengajaran dan pembelajaran. Kajian ini bertujuan untuk mengenal pasti pengaruh persepsi pelajar terhadap mass lecture dan motivasi mereka terhadap kepuasan belajar bahasa Arab komunikatif. Kaedah tinjauan digunakan dengan 597 respons sebagai dapatan berguna yang dikumpulkan dari sembilan fakulti berbeza di Universiti Teknologi MARA (UiTM). Kajian ini hanya melibatkan pelajar yang telah tamat kursus Bahasa Arab komunikasi tahap pertama. Untuk mengkaji bagaimana persepsi terhadap mass lecture dan motivasi mempengaruhi kepuasan, Permodelan Persamaan Berstruktur (SEM) Partial Least Squares (PLS) digunakan. Dapatan menunjukkan bahawa persepsi mass lecture mempengaruhi tahap motivasi dan kepuasan secara signifikan. Semakin tinggi motivasi pelajar, semakin tinggi kepuasan pelajar terhadap pembelajaran Bahasa Arab Komunikasi. Motivasi pelajar berpengaruh positif dan signifikan memediasi persepsi mass lecture terhadap kepuasan pelajar. Persepsi pelajar terhadap mass lecture adalah peramal kepuasan terpenting dengan nilai konstruk $84.4 \%$, diikuti dengan motivasi dengan $82 \%$. Dalam persekitaran pembelajaran secara online dan pengajian jarak jauh, model mass lecture adalah salah satu kaedah pengajaran yang cekap yang dapat meningkatkan motivasi dan kepuasan pelajar dalam mempelajari bahasa ketiga seperti bahasa Arab. Oleh itu, institusi pengajian tinggi yang mempunyai intake yang besar, boleh memilih kuliah besar-besaran untuk mata pelajaran berasaskan komunikatif seperti bahasa ketiga. Mass lecture juga boleh menjadi norma baru pada masa hadapan sebagai suatu cabaran dan alternatif dalam dunia pendidikan.
\end{abstract}

Kata kunci: bahasa Arab komunikasi, motivasi dan kepuasan pembelajaran, pendekatan mass lecture, pengajaran kolaboratif

\section{The Influence of Mass Lecture Approach and Motivation on the Satisfaction of Learning Arabic Communication}

\begin{abstract}
As customers of education, students' satisfaction in learning Arabic Language Communication is essential in the teaching and learning process. This study aims to identify the influence of learners' perception on mass lectures and their motivation on satisfaction of learning Arabic Language Communication. The survey method was employed with 597 usable responses collected from nine different faculties in Universiti Teknologi MARA (UiTM). Only students that have completed Arabic language courses level I is eligible to participate in the study. To investigate how perception on mass
\end{abstract}


lectures and motivation affects satisfaction, a structural equation modelling using Partial Least Squares (PLS) was deployed. Findings indicate that perception of mass lectures influences both motivation and satisfaction level significantly. The higher the learner's motivation, the more satisfied they are with learning Arabic communicative language. Motivation proves to mediate the relationship between perception of mass lectures and satisfaction. Learners' perception of mass lecture is the most important predictor of satisfaction with a construct value of $84.4 \%$, followed by motivation with $82 \%$. In today's open and distance learning environment, mass lecture models are one of the efficient teaching methods that can increase learners' motivation and satisfaction in learning third language such as Arabic. Thus, higher learning institutions with large number of enrollments can opt for mass lecture for communicative-based subjects such as third language, mass lecture also can become a new norm and alternative in the future.

Keywords: Arabic language communication, motivation and learning satisfaction, mass lecture approach, collaborative teaching

\section{Pengenalan}

Kemahiran Pengajaran dan Pembelajaran (PdP) abad ke-21 merujuk kepada beberapa kompetensi teras, iaitu kolaboratif, celik digital, kemahiran berfikir dan penyelesaian masalah. Bernet (2011) menjelaskan pembelajaran abad ke-21 sebagai suatu bentuk pembelajaran yang memerlukan pelajar menguasai isi kandungan dan menghasilkan, mensintesiskan iaitu penyatuan serta penggabungan, menilai maklumat mata pelajaran dan sumber yang luas dengan memahami dan menghormati budaya yang berbeza. Semua mata pelajaran perlu menekankan ciri pengajaran dan pembelajaran abad ke-21 termasuklah mata pelajaran Bahasa Arab Komunikasi di UiTM. Empat perkara utama yang ditekankan dalam pengajaran dan pembelajaran Abad ke-21 adalah komunikasi, pemikiran kritikal, kolaboratif dan kreativiti.

Pembelajaran Bahasa Arab sebagai bahasa ketiga di UiTM masih lagi mengamalkan PdP secara tradisional iaitu syarahan kecil dalam bentuk bersemuka dalam bilik darjah. Namun begitu, sejak tercetusnya pandemik Covid19 yang melanda di seluruh dunia, UiTM memerlukan kepada pembelajaran terbuka dan jarak jauh sebagai kaedah penyampaian. Pertemuan bersemuka antara pensyarah dan pelajar digantikan dengan PdP atas talian iaitu penggunaan teknologi tanpa sempadan sebagai norma baharu. Peralihan kaedah PdP konvensional kepada teknologi generasi kelima atau 5G ini adalah selari dengan pembelajaran Abad ke-21 yang berpandukan penglibatan aktif dalam bidang teknologi. Antara strategi pengajaran yang dipraktikkan di Akademi Pengajian Bahasa, Universiti Teknologi MARA adalah pengajaran menggunakan kaedah Mass Lecture (ML). Antara sebab dan tujuan pelaksanaan mass lecture ini adalah untuk mengurangkan kos menanggung perbelanjaan kewangan universiti untuk membayar gaji pensyarah sambilan yang ramai iaitu purata hampir 20 orang pensyarah bagi setiap semester. Justeru, pendekatan mass lecture adalah salah satu alternatif corak PdP atas talian untuk mengajar jumlah bilangan pelajar yang besar, iaitu purata setiap pensyarah mempunyai 450 sehingga 500 pelajar, di samping menampung kekurangan tenaga kerja pensyarah Bahasa Arab di UiTM Shah Alam, Selangor dalam pengajaran Bahasa Arab komunikasi. Walau bagaimanapun, mass lecture dilaksanakan dengan mengambil kira keperluan pelajar yang belajar secara maya dan pensyarah yang bekerja dari rumah (BDR). Tujuan utama kajian ini dijalankan adalah bagi membincangkan kaedah pelaksanaan PdP Bahasa Arab Komunikasi di UiTM secara mass lecture, dengan melihat pengaruh pembelajaran bahasa Arab Komunikasi, faktor minat dan motivasi, faktor jantina terhadap kepuasan pelajar belajar bahasa melalui mass lecture.

\section{Sorotan Literatur}

Pada bahagian akan menjelaskan tentang kaedah mass lecture dan hubungannya dengan teori pembelajaran bahasa yang sedia ada, iaitu teori pembelajaran behaviorisme, teori kognitif, teori sosial 
dan teori humanis. Kemudian diikuti dengan penjelasan mengenai motivasi dan kepuasan pembelajaran bahasa.

\section{Kaedah Mass lecture dan Teori Pembelajaran}

Dalam menghadapi jumlah pelajar yang terlalu ramai, kebanyakan universiti telah menjalankan kuliah secara mass lecture dengan meningkatkan jumlah pelajarnya tanpa limit dan batasan dalam bidang pengajian tertentu (Bowman \& Mete, 2014). Mass lecture yang seumpama ini telah dijalankan di institut pengajian tinggi di dalam dewan kuliah yang besar termasuklah kelas bahasa (Abdullah, Ramli \& Rafek, 2017). Mass lecture adalah merupakan kaedah pengajaran kolaboratif. Merujuk kepada Kamus Dewan, istilah kolaboratif bermaksud erat, dari segi kerjasama antara dua pihak ataupun lebih. Pembelajaran kolaboratif adalah istilah kepelbagaian pendekatan PdP yang melibatkan usaha intelektual bersama oleh pelajar atau pelajar dan sesama para guru. Seperti yang kita sedia maklum, dalam melaksanakan mass lecture, para guru akan membincangkan setiap topik dalam silibus dalam tempoh mass lecture. Menurut Mohammad et al. (2018) guru perlu mempelbagaikan strategi pengajaran mereka dari segi penyampaian bahan pembelajaran, interaksi dan aspek penyediaan suasana pembelajaran yang kondusif. Usaha ini akan dapat meningkatkan kepercayaan motivasi dan minat pelajar terhadap mata pelajaran Bahasa Arab sekali gus mengembangkan potensi penguasaan bahasa yang lebih berkesan dan komprehensif.

Sebelum itu dijelaskan sorotan ringkas tentang hubungan mass lecture dengan Bahasa Arab di Universiti Teknologi Mara UiTM. Bahasa Arab merupakan salah satu kursus bahasa ketiga yang ditawarkan di Universiti Teknologi MARA (UiTM), ia merupakan kursus wajib universiti kepada semua pelajar peringkat ijazah sarjana muda di setiap fakulti. Ia dikendalikan oleh Jabatan Bahasa Asia dan Eropah (JBAE) di bawah Unit Bahasa Arab (UBA), Akademi Pengajian Bahasa (APB). Pembelajaran berlaku selama 14 minggu diselangi beberapa ujian berterusan tanpa peperiksaan akhir. Ujian berterusan yang dijalankan adalah ujian bertulis, ujian mendengar, ujian lakonan simulasi dan ujian lakon peranan (roleplay). Ia merangkumi aspek kemahiran berbahasa iaitu kemahiran lisan, mendengar dan bertutur, membaca dan menulis.

Sebelum tercetusnya pandemik Covid19, PdP dijalankan dalam kelas fizikal secara bersemuka dalam purata bilangan pelajar antara 25 hingga 40 orang sahaja. Syarahan kecil ini dijalankan di bilik kuliah setiap fakulti yang terlibat, tiada pelaksanaan kuliah melalui Pendekatan Mass Lecture (PML) bagi bahasa ketiga. Namun begitu, sejak penularan pandemik Covid-19, semua institusi pengajian tinggi telah ditutup dan penyampaian kuliah dilaksanakan melalui penggunaan platform digital. Ini telah memberi impak yang besar bagi perubahan pengendalian kuliah bagi pihak pensyarah, pelajar dan universiti. Perubahan ini juga sudah tentu mempunyai implikasi tertentu dalam proses pembelajaran dan pemerolehan berbahasa. Akademi Pengajian Bahasa, UiTM telah memilih subjek bahasa Arab untuk dijadikan kajian rintis penyampaian kuliah bahasa ketiga secara mass lecture. PdP secara mass lecture atas talian melibatkan semua pensyarah Unit Bahasa Arab bermula dari penyediaan bahan sehingga lah pelaksanaan ujian berterusan. Antara alat pengajaran yang digunakan ialah Google Meet, Google Hangout, MS Team, Zoom, Telegram, WhatsApp dan aplikasi yang bersesuaian dengan PdP atas talian dengan mengambil kira kemudahan internet pelajar yang berada di kediaman masingmasing.

Dalam kaedah Mass Lecture (ML), pelaksanaannya tetap mengambil kira teori pembelajaran bahasa yang sedia ada. Namun begitu, berkemungkinan besar pelaksanaannya tidak tertumpu kepada satu teori sahaja. Ini disebabkan faktor pandemik yang melanda negara pada masa ini. Maka gaya pengajaran dan pembelajaran telah berubah. Antara teori tersebut adalah teori behavioris atau dikenali juga dengan teori rangsangan dan gerak balas, telah dipelopori oleh Ivan Pavlov (1849) dan dikembangkan oleh Thorndike dan Skinner, berpendapat bahawa pembelajaran adalah berkaitan dengan perubahan tingkah laku (Savignon, 2002). Antara implikasi pembelajaran dan pengajarannya ialah: (i) Setiap maklum balas pengajaran disampaikan dengan kerap, cepat dan terperinci, (ii) Menggunakan kaedah pengukuhan yang positif, tidak memadai dengan pengukuhan primer dan sekunder semata-mata, (iii) Mewujudkan pengukuhan yang berjadual dan bersistematik, (iv) menghindari tingkah laku yang negatif, (v) Pengukuhan bahasa adalah salah satu cara utama untuk meningkat motivasi pembelajaran 
pelajar, (vi) pembelajaran tertumpu kepada meningkatkan kemahiran dan sikap pelajar, dan (vii) pembelajaran yang mementingkan latih tubi (Savignon, 2002).

Seterusnya, teori pembelajaran kognitif mendapati bahawa pembelajaran ialah suatu proses perubahan yang berlaku dalam akal fikiran, dan tidak dapat diperhatikan secara langsung melalui tingkah laku. Menurut Wardsworth (1990), Piaget menjelaskan dalam kajiannya bahawa, manusia memiliki struktur kognitif, dan semasa proses pembelajaran, otak akan menyusun segala pernyataan dalam ingatan. Peranan guru amat penting, antara peranannya ialah (i) memberi peluang penerokaan maklumat kepada pelajar, (ii) guru adalah fasilitator, (iii) guru sentiasa memahami peringkat dan tahap mod pembelajaran pelajar, (iv) murid dibekalkan dengan bahan pembelajaran, aktiviti yang selaras dan sepadan dengan kognitif mereka, (v) memastikan kewujudan perkembangan kefahaman dan makna, (vi) diajar perkataan yang berada di persekitaran pelajar.

Justeru itu, wujudnya teori sosial di mana hasil gabungan di antara teori behavioris bersama dengan teori kognitif. Teori ini juga dikenal sebagai Teori Perlakuan Model. Albert Bandura (1997), menyatakan bahawa proses pembelajaran akan dapat dilaksanakan dengan lebih berkesan dengan menggunakan pendekatan pemodelan dan pemerhatian. Pelajar memerhati apa yang dilakukan atau disampaikan oleh guru dan meniru tindakan tersebut. Proses permodelan ini dapat membantu pelajar memahami apa yang dipelajari. Antara aktiviti yang dilakukan dalam pengajaran ialah (i) pelajar diberi peluang untuk memerhati dan mencontohi apa yang dipelajari, (ii) guru hendaklah menunjukkan lakuan berbahasa yang positif, (iii) guru menyediakan persekitaran sosial yang kondusif, (iv) guru hendaklah menyediakan intensif untuk meningkatkan motivasi, (v) perlu melihat kepada konteks, (vi) bahan hendaklah sesuai dan seimbang.

Akhir sekali, teori humanis yang berpendapat pembelajaran bahasa itu bergantung kepada emosi dan perasaannya. Menurut Raskin (2005), Carl Rogers menyatakan bahawa setiap individu itu mempunyai gaya belajar yang tidak sama antara seorang pelajar dengan yang lain. Oleh karena itu, strategi dan pendekatan dalam aktiviti pengajaran dan pembelajaran hendaklah dirancang dan disusun mengikut kehendak dan perkembangan emosi pelajar. Beliau juga menjelaskan bahawa setiap individu mempunyai potensi dan keinginan untuk mencapai kesempurnaan diri. Maka, guru hendaknya sentiasa prihatin terhadap psikologi pelajar, serta memberi bimbingan supaya kemahiran mereka dapat diperkembangkan ke tahap yang optimum. Antara perkara yang perlu diberi perhatian ialah, (i) Kesedaran guru terhadap keperluan asas yang sepatutnya dipenuhi terlebih dahulu bagi setiap pelajar, (ii) guru perlu mengenal pasti kekurangan pelajar, (iii) pemilihan tugasan hendaklah dapat merangsang minat pelajar untuk terus mengikuti pembelajaran.

\section{Motivasi dalam Pembelajaran}

Menurut Ricardo (2017) pelajar yang mempunyai minat dan motivasi yang tinggi lazimnya akan dikaitkan dengan prestasi akademik yang baik. Hanifal et al. (2019) pula menyatakan dalam kajian mereka bahawa terdapat hubungan yang signifikan antara motivasi belajar dan minat belajar secara bersama-sama dengan hasil belajar bahasa Arab. Motivasi yang baik dapat menggalakkan pelajar untuk terus berusaha gigih dalam pembelajaran Bahasa Arab. Zaliza et al. (2014) menyatakan peranan guru dan masyarakat sangat penting dalam meningkatkan motivasi pembelajaran bahasa. Menurut Nuraisyah (et . al., 2021) terdapat hubungan signifikan yang sederhana antara motivasi dan pencapaian akademik dalam pembelajaran regulasi kendiri terhadap pencapaian akademik. Peranan guru yang mahir mengurus bahan pengajaran akan dapat meningkatkan minat dan motivasi pembelajaran pelajar. Malah guru yang bijak hendaklah mahir untuk mengurus penilaian dengan baik dan secara sistematik, dikatakan dapat membantu meningkatkan motivasi pelajar. Dalam beberapa kajian, dinyatakan pembahagian motivasi iaitu motivasi intrinsik iaitu berbentuk dorongan dalam diri seperti kesedaran diri dan motivasi ekstrinsik adalah faktor luaran (Rosmaza et al., 2016), konsep media dan gaming dapat menghilangkan rasa bosan dan meningkat motivasi pembelajaran sepanjang proses pembelajaran bahasa Arab. Menurut Farah et al. (2021) berdasarkan ujian-t yang dijalankan terhadap pelajar UPM mendapati pelajar bermotivasi tinggi sekiranya pembelajaran kendiri menggunakan gaya pembelajaran secara visual dan kinestatik. Pada sudut pandangan lain menurut Adtya et al. (2018), faktor intrinsik mengenai kesedaran dalam diri seseorang mengenai kepentingan kerja di mana akan datang hasil kerja 
tersebut akibat daripada usaha yang dilakukan. Ritchie et al. (2021) mendapati bahan pengajaran yang berbentuk permainan dapat meningkatkan motivasi intrinsik pelajar. Maka dalam proses pengajaran bahasa secara kolaboratif, perlu penggabungan gaya pembelajaran dan pengajaran seperti dijelaskan tadi supaya motivasi dapat ditingkatkan. Pentakrifan ini boleh digunakan atas tujuan untuk melonjakkan keinginan pelajar untuk mencapai sesuatu matlamat yang ditetapkan. Pendidikan Alaf ke21 (PAK 21), menggalakkan penggunaan teknologi sebagai salah satu kaedah pengajaran dan pembelajaran sebagai usaha untuk membuka minda pelajar dan meningkatkan minat dan motivasi di kalangan mereka (Mohd Syuhaidi et al., 2018).

\section{Kepuasan Pembelajaran Bahasa}

Kepuasan merupakan suatu perasaan dimana mengharapkan satu keinginan yang menenangkan jiwa dari sebuah pelayanan (Aktan, 2010). Dalam kepuasan pembelajaran, pelayanan yang dimaksudkan adalah pelayanan pembelajaran yang pelajar patut perolehi. Oleh karena itu, kepuasan belajar bahasa dapat didefinisikan sebagai suatu kondisi perasaan puas karena terpenuhinya harapan dari sebuah kegiatan pembelajaran yang dialami oleh pelajar. Menurut Wu, et.al (2015) juga menyebutkan bahawa teori tentang kepuasan belajar (learning satisfactory theory) merupakan sebuah teori yang dikembangkan dari teori kepuasan consumer behavior (customer satisfaction theory) oleh Cardozo (1965). Oleh karena pelajar merupakan pelanggan bagi sesebuah institusi, selari dengan teori kepuasan pelanggan maka kepuasan pelajar belajar juga boleh dinilai berdasarkan respons atas suatu kegiatan (pembelajaran dan pengajaran) berdasarkan perbandingan antara harapan dan kenyataan yang mereka terima. Kepuasan belajar juga merupakan kemampuan emosional (emotional affordance) (Calli, et.al, 2013 dalam Ekoto 2015) dan ia persepsinya akan bersifat subjektif (subjective perceptions) tentang suatu situasi pembelajaran. Oleh yang demikian, kepuasan pelajar dalam pembelajaran bahasa sangat penting untuk diperhatikan kerana mereka adalah aset dalam pendidikan yang terpenting (Ko, 2012). Maka kajian ini, berhasrat untuk melihat beberapa faktor yang mempengaruhi dan faktor yang dipengaruhi oleh kepuasan pelajar dalam pembelajaran bahasa.

\section{Metod Kajian}

Kajian ini berasaskan pendekatan kuantitatif secara soal selidik. Responden terdiri daripada pelajar Bahasa Arab di Universiti Teknologi MARA yang mendaftar kursus Bahasa Arab Tahap 1. Seramai 597 orang responden yang terlibat sebagai subjek kajian yang terdiri dari tiga kampus utama iaitu UiTM Kampus Shah Alam, Kampus Puncak Perdana dan Kampus Puncak Alam. Soal Selidik digunakan sebagai instrumen untuk meninjau persepsi pelajar berkaitan pengaruh pembelajaran secara Mass Lecture, minat dan motivasi dan jantina terhadap penggunaan tahap kepuasan pelajar belajar bahasa. Data yang diperoleh telah dianalisis menggunakan perisian SPSS versi 26.0. Ujian statistik dihurai secara deskriptif bagi memerihalkan maklumat profil demografi responden iaitu jantina, umur, pengalaman belajar bahasa Arab, fakulti dan lokasi responden. Kemudian, analisis SEM dengan menggunakan aplikasi SmartPLS 3.0 digunakan untuk melihat pengaruh faktor pembelajaran secara kaedah Mass Lecture $(M L)$, minat dan motivasi pelajar, jantina terhadap kepuasan pelajar.

\section{Analisis Data}

Teknik analisis data dalam penyelidikan adalah menggunakan IBM SPSS versi 26.0 dan Structural Equation Modelling (SEM) dengan perisian Partial Least Squares (SmartPLS 3.0) sebagai alat analisis. PLS adalah satu kaedah alternatif yang bersifat prediktif yang berbaris berguna dalam pembentukan SEM (Ghozali, 2006). SmartPLS juga dapat digunakan dalam kajian berbentuk pengesahan (confirmatory) sama ada untuk menerima atau menolak teori, atau boleh juga digunakan untuk membangunkan teori dalam kajian penerokaan (Hair et al., 2018). Analisis statistik deskriptif digunakan bagi menjelaskan profil demografi responden. Analisis SEM-SmartPLS diaplikasikan bagi menjawab hipotesis dan menentukan pengaruh antara pemboleh ubah eksogen dan pemboleh ubah endogen. 


\section{Instrumen}

Instrumen yang digunakan adalah berbentuk borang soal selidik tertutup yang dibangunkan oleh Nor Hidayati e al. (2017), Ni Putu et al. (2020) berkaitan dengan pembelajaran. Manakala Rais dan Eka (2019) berkaitan dengan kepuasan. Semua instrumen tersebut telah diubah suai berdasarkan keperluan kajian dan fokus semasa. Instrumen kajian ini mempunyai lima bahagian yang melibatkan set-set data. Bahagian A adalah maklumat demografi seperti nama, jantina, umur, pengalaman belajar Bahasa Arab. Bahagian B mempunyai skala likert tujuh mata yang mempunyai 5 item bagi mengukur persepsi pelajar terhadap pembelajaran bahasa Arab dengan kaedah Mass Leture $(M L)$. Bahagian C mempunyai 8 item bagi mengukur persepsi minat dan motivasi di kalangan pelajar, skala yang digunakan ialah skala tujuh likert. Bahagian D mempunyai 5 item untuk mengukur kepuasan pelajar dalam pembelajaran secara mass lecture. Semua sekala likert 7 mata menggunakan skala sangat tidak setuju kepada sangat setuju.

\section{Hasil Kajian}

\section{Maklumat Responden}

Jadual 1 menunjukkan profil jantina responden yang terlibat dalam kajian ini, iaitu sebanyak 206 $(34.5 \%)$ terdiri daripada pelajar lelaki dan perempuan pula adalah 391 (65.5\%). Jumlah keseluruhan adalah 597 responden.

Jadual 1: Profil Jantina Responden

\begin{tabular}{lcc}
\hline Jantina & Frekuensi & Peratus \\
\hline Lelaki & 206 & 34.5 \\
Perempuan & 391 & 65.5 \\
Total (N) & 597 & 100.0 \\
\hline
\end{tabular}

Jadual 2 menunjukkan profil umur responden dalam kajian ini, dapatan menunjukkan hanya terdapat tiga tahap umur sahaja yang mendaftar kursus Bahasa Arab tahap TAC 401 ini, Pertama yang berumur 21 tahun $390(65.3 \%)$, kedua ialah 22 tahun 195 (32.7\%) dan ketiga 23 tahun $12(2 \%)$.

Jadual 2: Profil Umur Responden Kajian

\begin{tabular}{ccc}
\hline Umur & Frekuensi & Peratus \\
\hline 21 & 390 & 65.3 \\
22 & 195 & 32.7 \\
23 & 12 & 2.0 \\
\hline Total (N) & 597 & 100.0 \\
\hline
\end{tabular}

Jadual 3 adalah profil pengalaman responden belajar bahasa Arab yang telah mendaftar kursus ini. Sebanyak 384 (64.3\%) mempunyai pengalaman belajar bahasa Arab 1-3 tahun. Manakala responden yang berpengalaman 4-5 tahun sebanyak 109 (18.3\%), dan 6 tahun ke atas adalah 104 (17.4\%).

Jadual 3: Profil Pengalaman Responden

\begin{tabular}{lrc}
\hline Pengalaman & Frekuensi & Peratus \\
\hline 1 - 3 tahun & 384 & 64.3 \\
4 - 5 tahun & 109 & 18.3 \\
6 tahun dan ke atas & 104 & 17.4 \\
\hline
\end{tabular}


Jadual 4 menunjukkan maklumat fakulti dan lokasi kajian dijalankan. Seramai $36(6 \%)$ dari fakulti AC, $56(9.4 \%)$ dari fakulti AD, $13(2.2 \%)$ dari fakulti AP, $114(19.1 \%)$ dari fakulti AS, $82(13.7 \%)$ dari fakulti BM, $148(24.8 \%)$ dari fakulti CS, 33 (5.5\%) dari fakulti ED, 60 (10.1\%) dari fakulti EE dan 55 (9.2\%) dari fakulti IM. Lokasi yang terlibat dalam kajian ini ialah UiTM Puncak Alam yang melibatkan fakulti AC, AD, BM. Lokasi Shah Alam melibatkan fakulti AP, CS dan ED, manakala IM dari UiTM Puncak Perdana.

Jadual 4: Profil Fakulti dan Lokasi Responden Kajian

\begin{tabular}{lcc}
\hline \multicolumn{1}{c}{ Fakulti / Lokasi } & Frekuensi & Peratus \\
\hline AC-Perakaunan (Puncak Alam) & 36 & 6.0 \\
AD- Seni Lukis \& Seni Reka (Puncak Alam) & 56 & 9.4 \\
AP-Perancangan Ukur (Shah Alam) & 13 & 2.2 \\
AS-Sains Gunaan (Shah Alam) & 114 & 19.1 \\
BM-Pengurusan Perniagaan (Puncak Alam) & 82 & 13.7 \\
CS- Sains Komputer (Shah Alam) & 148 & 24.8 \\
ED-Pendidikan (Shah Alam) & 33 & 5.5 \\
EE-Kejuruteraan Elektrik (Shah Alam) & 60 & 10.1 \\
IM-Pengurusan Maklumat (Puncak Perdana) & 55 & 9.2 \\
\hline Total (N) & 597 & 100.0 \\
\hline
\end{tabular}

\section{Model Kerangka Kajian}

Rajah 1 menunjukkan kerangka kajian yang menggunakan model pengukuran reflektif, maka beberapa hipotesis dibuat dengan mengambil kira hasil dan sumbangan kajian sebelumnya untuk mengenal pasti hasilan kajian melalui sebilangan pemboleh ubah utama yang dikenal pasti seperti kepuasan, jantina, pembelajaran, minat dan motivasi.

\section{Rajah 1: Model Kerangka Kajian}

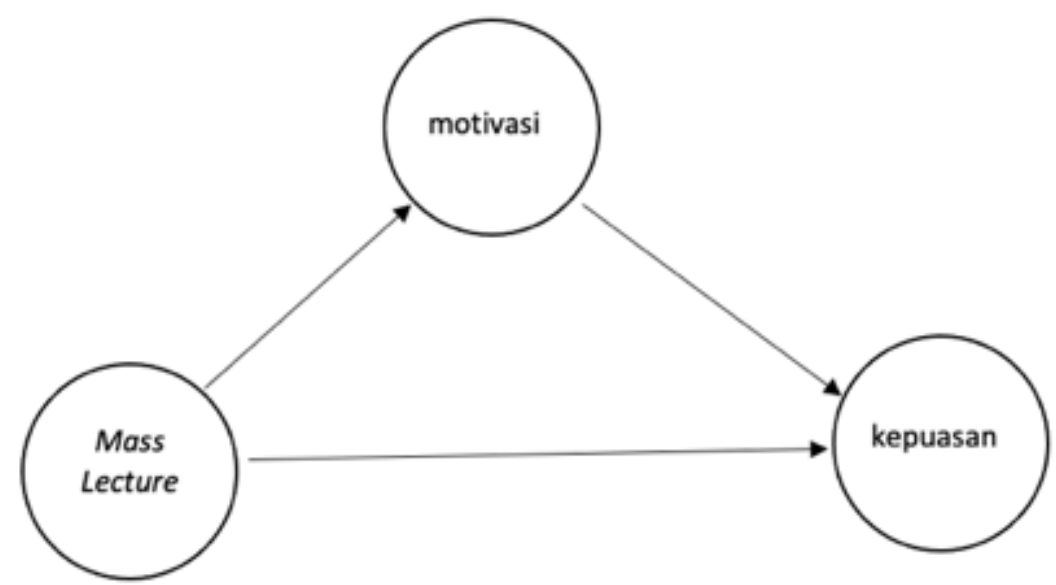

$\mathrm{H}_{1}$ : Terdapat pengaruh Mass Lecture (ML) terhadap Kepuasan Pelajar (KPS).

$\mathrm{H}_{2}$ : Terdapat pengaruh Mass Lecture (ML) terhadap Motivasi Pelajar (MP).

$\mathrm{H}_{3}$ : Terdapat pengaruh Motivasi Pelajar (MP) terhadap Kepuasan Pelajar (KPS)

$\mathrm{H}_{4}$ : Motivasi Pelajar memediasi pengaruh persepsi Mass Lecture terhadap Kepuasan Pelajar (KPS). 


\section{Analisis Kesahan dan Kebolehpercayaan}

Berdasarkan model pengukuran reflektif di atas, penilaian akan dilakukan dari kriteria indicator reliability, internal consistency reliability, convergent validity dan discriminant validity. Analisis convergent validity dilakukan pada outer loadings bagi melihat nilai setiap indikator iaitu setiap loading perlu mencapai nilai lebih tinggi dari 0.708 , bagi setiap indikator yang tidak mencapai 0.708 perlu disingkirkan. Proses penyingkirannya hendaklah tidak melebihi $20 \%$ dari keseluruhan item kajian. Proses penyingkiran item ini juga dinamakan confirmatory factor analysis (Hair et. al. 2018). Dalam kajian ini, untuk melihat internal consistency reliability maka nilai composite reliability (CR) adalah lebih tinggi 0.708 dan average variance extracted (AVE) adalah lebih tinggi dari 0.5. Selain itu, nilai Cronbach's alpha (CA) akan diambil kira dengan melihat perbandingan nilai yang tertinggi. Apabila konstruk telah mencapai nilai CR, CA dan AVE yang ditetapkan, maka konstruk juga dikatakan telah mencapai tahap convergent validity kajian. Rajah 2 menunjukkan hubungan setiap konstruk dan nilai bagi setiap konstruk dan nilai setiap konstruk adalah lebih tinggi dari 0.708 , maka diterima semuanya.

\section{Rajah 2: Outer Loadings Konstruk}

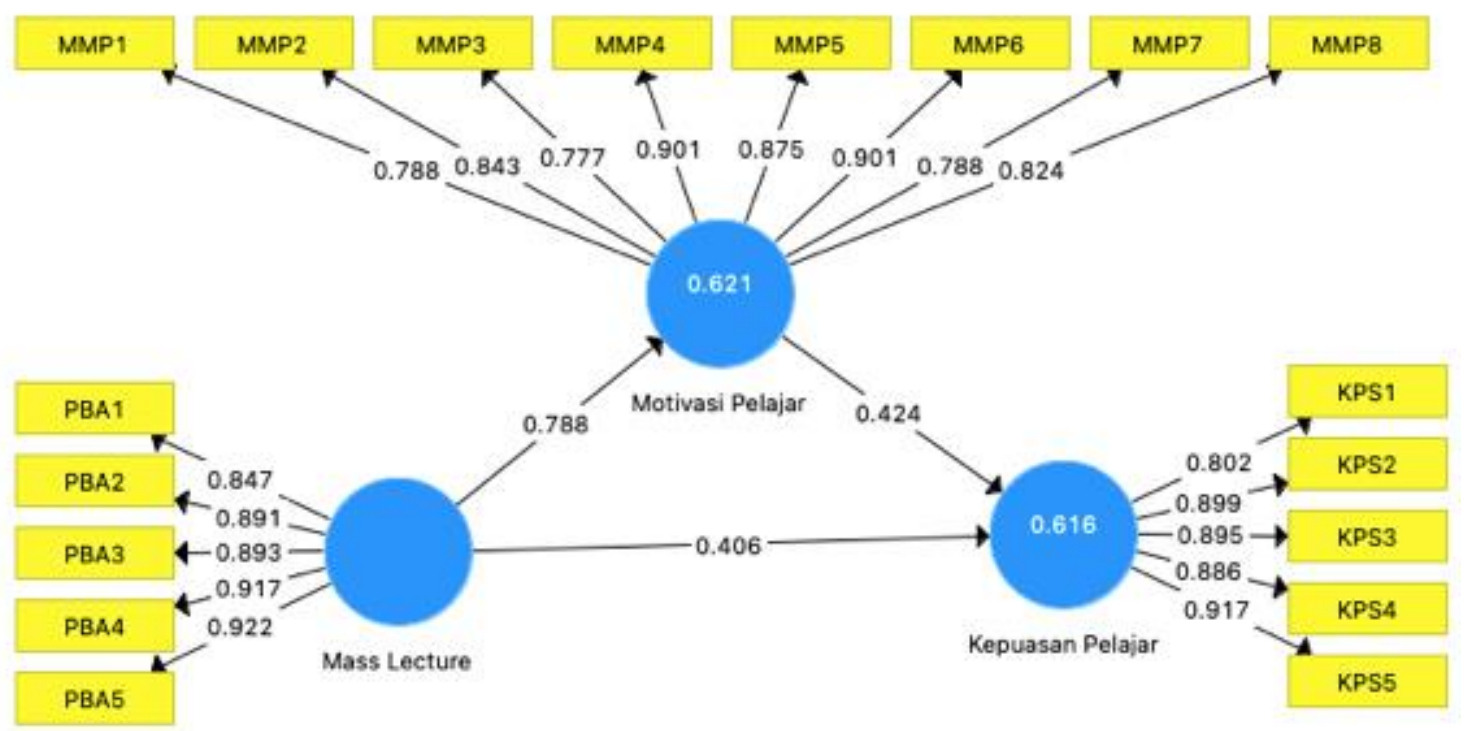

\section{Analisis Convergent Validity}

Analisis Convergent Validity adalah untuk mendapatkan kesahan berdasarkan kepada dua kriteria iaitu faktor Loading dan Average Variance Extracted (AVE). Tujuannya ialah untuk melihat sejauh mana sesuatu indikator bagi setiap konstruk mempunyai hubungan dengan indikator lain atau indikator alternatif yang mengukur konstruk yang sama. Oleh itu, item-item pada setiap konstruk tertentu mestilah menunjukkan varian yang tinggi antara satu sama lain supaya ia dapat menjelaskan konstruk yang diukur (Norazwa et al., 2021). Syarat signifikan bagi outer loading ialah perlu mencapai nilai sekurang-kurangnya 0.708 (Hair et al., 2018).

Berdasarkan jadual 5, Item-item bagi setiap konstruk dalam Analisa cross loadings bagi KPS1 sehingga KPS5, ML1 sehingga ML5 dan MP1 sehingga MP8 adalah lebih tinggi dari 0.07, maka dengan itu semuanya diterima, ini bererti hubungan antara setiap indikator dalam mengukur strukturstruktur adalah signifikan.

Nilai Composite Reliability (CR) dan nilai Cronbach's Alpha (CA), menurut Hair di mana lebih tinggi nilai CR menandakan bahawa tahap kebolehpercayaan adalah tinggi. Nilai CR antara 0.6 dan 0.7 adalah diterima dalam kajian penerokaan, manakala dalam kajian lain nilai di antara 0.7 dan 0.9 adalah memuaskan (Hair et al., 2018). Berdasarkan jadual 5, nilai Composite Reliability (CR) terhadap KPS 
DOI: https://doi.org/10.47405/mjssh.v6i10.1062

adalah 0.945 lebih tinggi dari 0.7, nilai CR terhadap ML adalah 0.952 lebih tinggi dari 0.7 , nilai CR terhadap MP adalah 0.950 lebih tinggi dari 0.7. Ini bererti tahap kebolehpercayaan item dalam setiap konstruk berada pada tahap kebolehpercayaan yang tinggi dan nilai pada setiap item adalah reliable.

Pada masa yang sama, nilai skor purata bagi AVE hendaklah sama atau lebih tinggi dari 0.5 (Hair et al., 2018). Berdasarkan jadual 5, didapati bahawa nilai AVE bagi konstruk KPS 0.775 lebih tinggi dari 0.5, nilai AVE bagi konstruk MP 0.703 lebih tinggi dari 0.5, nilai AVE bagi ML 0.800 lebih tinggi dari 0.5. Manakala nilai Cronbach's Alpha (CA) terhadap KPS adalah 0.928 lebih tinggi dari 0.7, nilai CA terhadap MP adalah 0.939 lebih tinggi dari 0.7, nilai CA terhadap ML adalah 0.937 lebih tinggi dari 0.7. Kesimpulannya, semua konstruk kajian telah mencapai piawaian yang disyaratkan dalam analisa Convergent Validity.

Jadual 5: Dapatan Nilai Loadings, Cronbach's Alpha (CA), Composite Reliability (CR) d an Average Variance Extracted (AVE)

\begin{tabular}{llcccc}
\hline Konstruk & Item & Loadings & CA (>0.07) & CR (>0.07) & AVE (>0.05) \\
\hline Kepuasan & KPS1 & 0.802 & 0.928 & 0.945 & 0.775 \\
& KPS2 & 0.899 & & & \\
& KPS3 & 0.895 & & & \\
KPS4 & 0.886 & & & \\
& KPS5 & 0.917 & & 0.952 & \\
& ML1 & 0.847 & 0.937 & & \\
Motivasi & ML2 & 0.891 & & & \\
& ML3 & 0.893 & & & \\
& ML5 & 0.917 & & & \\
& MP1 & 0.922 & & & \\
& MP2 & 0.788 & & & \\
& MP3 & 0.743 & & & \\
& MP4 & 0.901 & 0.939 & & \\
& MP5 & 0.875 & & & \\
& MP6 & 0.901 & & & \\
& MP7 & 0.788 & & & \\
& MP8 & 0.824 & & & \\
& &
\end{tabular}

Outer Loadings, Cronbach's Alpha (CA), Composite Reliability (CR), Average Variance Extracted (AVE)

\section{Analisis Discriminant Validity}

Discriminant Validity atau kesahan pembezaan adalah proses analisa kesahan dan kebolehpercayaan yang merujuk kepada sejauh mana indikator dalam sesuatu konstruk berbeza dengan indikator konstruk lain yang dinilai menerusi korelasi dalam sesebuah model kajian. Pengukuran dibuat ke atas nilai indikator pada konstruk tertentu yang disyaratkan mempunyai nilai loading yang lebih besar berbanding nilai loading indikator pada konstruk yang lain (Hair et al., 2018; Norazwa et al., 2021). Ini dapat membuktikan keunikan setiap konstruk dan mengukur fenomena yang tidak diukur oleh konstruk yang lain. Pengujian ini melihat kepada nilai Cross Loading (CL), Fornell Larcker, HererotraitMonotrait Ratio (HTMT) dan Confidence Interval (CI).

Jadual 6 menunjukkan dapatan analisis Fornell-Larcker, apabila nilai kuasa dua adalah lebih besar daripada elemen bukan pepenjuru bagi setiap konstruk dan lajur. Ini menunjukkan pembinaan konstruk mempunyai hubungan yang kuat dengan indikator yang diwakili (Hair et al., 2018). Dapatan menunjukkan nilai kolerasi pada KPS (0.881), ML (0.894) dan MP (0.838) adalah lebih besar dari nilai korelasi lain dalam kolum yang sama, maka Discriminant Validity telah berjaya dicapai. 
DOI: https://doi.org/10.47405/mjssh.v6i10.1062

Jadual 6: Analisis Kesahan Diskriminan Fornell-Larcker Criterion

\begin{tabular}{lccc}
\hline & Kepuasan Pelajal & Mass Lecture & Motivasi Pelajar \\
\hline KPS & $\mathbf{0 . 8 8 1}$ & & \\
ML & 0.740 & $\mathbf{0 . 8 9 4}$ & \\
MP & 0.744 & 0.788 & $\mathbf{0 . 8 3 8}$ \\
\hline
\end{tabular}

Fornell-Larcker Criterion

Jadual 7 menunjukkan analisis Cross Loading indikator pada setiap konstruk, paparan menunjukkan Cross loading dari setiap item bagi setiap konstruknya lebih besar dari nilai loading dengan konstruk yang lainnya pada kolum yang sama. Kesimpulannya, setiap indikator berada pada konstruk masingmasing, maka Discriminant Validity telah berjaya dicapai.

Jadual 7: Loadings dan Cross Loadings

\begin{tabular}{|c|c|c|c|}
\hline Item & Kepuasan Pelajar & Mass Lecture & Motivasi Pelajar \\
\hline KPS1 & 0.802 & 0.773 & 0.589 \\
\hline KPS2 & 0.899 & 0.597 & 0.579 \\
\hline KPS3 & 0.895 & 0.573 & 0.573 \\
\hline KPS4 & 0.886 & 0.588 & 0.606 \\
\hline KPS5 & 0.917 & 0.664 & 0.663 \\
\hline ML1 & 0.578 & 0.847 & 0.602 \\
\hline ML2 & 0.650 & 0.891 & 0.691 \\
\hline ML3 & 0.658 & 0.893 & 0.693 \\
\hline ML4 & 0.713 & 0.917 & 0.759 \\
\hline ML5 & 0.699 & 0.922 & 0.764 \\
\hline MP1 & 0.528 & 0.551 & 0.788 \\
\hline MP2 & 0.616 & 0.668 & 0.843 \\
\hline MP3 & 0.526 & 0.580 & 0.777 \\
\hline MP4 & 0.683 & 0.739 & 0.901 \\
\hline MP5 & 0.695 & 0.752 & 0.875 \\
\hline MP6 & 0.662 & 0.664 & 0.901 \\
\hline MP7 & 0.579 & 0.575 & 0.788 \\
\hline MP8 & 0.664 & 0.713 & 0.824 \\
\hline
\end{tabular}

Loadings, Cross Loadings

Seterusnya, analisis diskriminan Heterotrait-Monotrait Ratio (HTMT) adalah alternatif penambahbaikan dari kriteria Fornell-Larcker. Jika nilai HTMT adalah lebih kecil dari 0.90 (Gold et al., 2001) dan HTMT lebih kecil dari 0.85 (Kline, 2011) menunjukkan kesahan diskriminan tercapai. HTMT juga dapat dicapai dengan nilai confidence interval (CI) yang diperoleh tidak lebih dari nilai 1.0 pada setiap konstruk (Henseler et al, 2015).

Jadual 8 menunjukkan nilai HTMT ML adalah 0.776 lebih kecil dari 0.90, dan nilai HTMT bagi MP adalah 0.830 lebih kecil dari 0.90. Dapatan menunjukkan bahawa tidak terdapat masalah dalam memenuhi keperluan Discriminant Validity.

Jadual 8: Analisis Kesahan Diskriminan Heterotrait-Monotrait Ratio (HTMT)

\begin{tabular}{lll}
\hline & Kepuasan Pelajar & Mass Lecture \\
\hline Kepuasan Pelajar & & \\
Mass Lecture & $\mathbf{0 . 7 7 6}$ & \\
Motivasi Pelajar & 0.776 & $\mathbf{0 . 8 3 0}$ \\
\hline
\end{tabular}

Heterotrait Monotrait Ratio (HTMT) 
Manakala jadual 9 menunjukkan pengaruh nilai upper dan lower dalam confidence interval $(\mathrm{CI})$ terhadap konstruk yang dikaji adalah lebih kecil dari 1.0. Maka bererti bahawa kesahan diskriminan adalah valid.

Jadual 9: Analisis Kesahan Diskriminan Confidence Interval

\begin{tabular}{lllll}
\hline Hubungan & $\begin{array}{l}\text { Original } \\
\text { Sample (O) }\end{array}$ & $\begin{array}{l}\text { Sample Mean } \\
(\mathbf{M})\end{array}$ & $\mathbf{2 . 5 \%}$ & $\mathbf{9 7 . 5 \%}$ \\
\hline Mass Lecture -> Kepuasan Pelajar & 0.406 & 0.406 & 0.298 & 0.510 \\
Mass Lecture -> Motivasi Pelajar & 0.788 & 0.791 & 0.740 & 0.826 \\
$\begin{array}{l}\text { Motivasi Pelajar -> Kepuasan Pelajar } \\
\text { Mass Lecture -> Motivasi Pelajar -> Kepuasan }\end{array}$ & 0.424 & 0.423 & 0.315 & 0.527 \\
Pelajar & 0.334 & 0.335 & 0.249 & 0.412 \\
\hline
\end{tabular}

Confidence Interval

Setelah ujian internal consistency reliability (CR), convergent validity dan discriminant validity selesai dilaksanakan. Paparan nilai-nilai membuktikan model yang dirangka menerusi konstruk dan indikatornya telah mencapai kesahan dan kebolehpercayaan telah tercapai (fit). Maka konstruk reflektif adalah sesuai untuk PLS-SEM dan dapat diteruskan kepada analisis penilaian model struktural iaitu inner model kerana semua syarat telah dipenuhi.

\section{Analisis Model Struktural}

Setelah semua indikator dan konstruk memenuhi syarat Indicator Reliability, Internal Consistency Reliability, Composite Reliability, Convergent Validity dan Discriminant Validity, maka diteruskan dengan analisis model struktural bagi memperoleh maklumat tentang hubungan antara konstruk dalam model iaitu path coefficient (ß) sama ada hubungan tersebut signifikan atau sebaliknya. Bererti bahawa model ini akan dapat menjawab persoalan sama ada konstruk eksogenous memberi kesan ke atas konstruk endogenuos atau sebaliknya, seterusnya membolehkan hipotesis kajian diterima atau ditolak. Pada bahagian ini, pemerhatian akan dibuat terhadap kriteria coefficient of determinition $\left(\mathrm{R}^{2}\right)$, penilaian effect size $\left(\mathrm{f}^{2}\right)$, predictive relevance $\left(\mathrm{Q}^{2}\right)$ dan penilaian effect size $\left(\mathrm{q}^{2}\right)$. Langkah pertama yang harus dilakukan adalah pengujian collinearity. Sehubungan itu, sesuatu konstruk dinilai dari aspek collinearity nya sebelum penilaian model struktural dijalankan.

\section{Hasil Pengujian Collinearity}

Berdasarkan jadual 10 menunjukkan nilai yang dicatatkan oleh semua konstruk peramal. Dapatan menunjukkan bahawa semua konstruk peramal bebas dari isu collinearity berdasarkan nilai dalam lingkungan $0.2<$ VIF $<5.0$ (Hair et al., 2018).

Jadual 10: Keputusan Penilaian Collinearity

\begin{tabular}{lccc}
\hline Konstruk & Kepuasan Pelajar & Mass Lecture & Motivasi Pelajar \\
\hline Kepuasan Pelajar & 2.639 & \\
Mass Lecture & 2.639 & & 1.000 \\
Motivasi Pelajar & & \\
\hline
\end{tabular}

Collinearity Statistic (VIF)

\section{Hasil Pengujian Signifikan dan Relevan}

Jadual 11 menunjukkan keputusan penilaian model struktural. Hasil analisis membuktikan bahawa semua hipotesis berpengaruh positif apabila semua nilai pada $\beta$ masing-masing adalah positif. Aras keyakinan bagi pengaruh mass lecture terhadap kepuasan pelajar adalah 0.406, mass lecture terhadap motivasi adalah 0.788 , motivasi terhadap kepuasan adalah 0.424 dengan nilai $\mathrm{t}$ masing-masing adalahlah 8.015, 38.044 dan 8.556 iaitu lebih besar dari 1.96 (Hair et al., 2018). Manakala aras keyakinan bagi mediasi mass lecture dengan motivasi terhadap kepuasan adalah 0.334 dengan nilai $\mathrm{t}$ 
adalah 8.668. Ujian ini juga membuktikan bahawa mass lecture adalah peramal tertinggi bagi semua peramal exogenous iaitu sebanyak $78.8 \%$. Didapati juga bahawa motivasi $(42.4 \%)$ merupakan peramal paling penting ke atas kepuasan pelajar berbanding mass lecture (40.6\%).

Jadual 11: Dapatan Keputusan Analisis Signifikan dan Relevan

\begin{tabular}{lllll}
\hline Hipotesis & $\begin{array}{l}\text { Path Coeficier } \\
(\mathbf{B})\end{array}$ & Nilai-P & Nilai-T & Keputusan \\
\hline Mass Lecture -> Kepuasan Pelajar & 0.406 & 0.000 & 8.015 & Diterima \\
Mass Lecture -> Motivasi Pelajar & 0.788 & 0.000 & 38.044 & Diterima \\
Motivasi Pelajar -> Kepuasan Pelajar & 0.424 & 0.000 & 8.556 & Diterima \\
Mass Lecture -> Motivasi Pelajar -> & 0.334 & 0.000 & 8.668 & Diterima \\
Kepuasan Pelajar & & &
\end{tabular}

$T>1.96$ dan $p<0.05$

\section{Keputusan Coefficient of Determinition ( $\left.\mathrm{R}^{2}\right)$-Goodnees-of-fit}

Jadual 12 menunjukkan Model Struktur nilai $R$-Square $\left(\mathrm{R}^{2}\right)$ yang merupakan pengujian goodnees-of-fit model iaitu untuk membuat ujian ketepatan jangkaan model. Menurut Hair et al. (2018) hasil penilaian $\mathrm{R}^{2}$ terbahagi kepada tiga tahap iaitu besar $(0.75)$, sederhana $(0.50)$ dan kecil $(0.25)$.

Kesan Varian yang ditunjukkan oleh kepuasan pelajar adalah pada tahap sederhana iaitu memiliki nilai $\mathrm{R}^{2}$ sebanyak 0.614 iaitu sebanyak $61.4 \%$ variabel kepuasan dapat dijelaskan oleh variabel motivasi dan mass lecture, manakala $38.6 \%$ varian kepuasan diterangkan oleh faktor-faktor lain yang tidak menjadi fokus dalam kajian ini. Bagi motivasi pelajar juga berada pada tahap sederhana, nilai $\mathrm{R}^{2}$ adalah 0.620 iaitu $62 \%$ varian motivasi dijelaskan oleh varian mass lecture, manakala $38 \%$ dijelaskan oleh varian di luar kajian ini.

Jadual 12: Analisis R-Square Coefficients

\begin{tabular}{lcc}
\hline Variabel & R Square $\left(\mathbf{R}^{\mathbf{2}}\right)$ & Tahap \\
\hline Kepuasan Pelajar & 0.614 & Sederhana \\
Motivasi Pelajar & 0.620 & Sederhana \\
\hline
\end{tabular}

$R$-Square Coefficients

\section{Keputusan $\mathbf{f}^{2}$ (Effect Size)}

Jadual 13 menunjukkan nilai $\mathrm{f}^{2}$ bagi setiap konstruk tidak bersandar ke atas konstruk bersandar. Keputusan menunjukkan bahawa mass lecture dan motivasi memberi kesan yang sederhana dalam menghasilkan $\mathrm{R}^{2}$ untuk KPS dengan nilai masing-masing yang diperoleh adalah 0.162 dan 0.178 . tetapi motivasi merupakan paling substansif berbanding dengan mass lecture dalam menghasilkan $\mathrm{R}^{2}$ untuk KPS. Manakala motivasi juga memberi kesan sederhana 1.639 dalam menghasilkan $\mathrm{R}^{2}$ untuk MP. Menurut Hair et al. (2018), nilai kriteria adalah berdasarkan tiga kategori iaitu besar (0.35), sederhana (0.15) dan kecil (0.02).

Jadual 13: Kesan Sebenar Konstruk Tidak Bersandar ke atas Konstruk Bersandar

\begin{tabular}{lcc}
\hline & \multicolumn{2}{c}{ Kesan sebenar yang ditunjukkan oleh IV kepada DV } \\
\hline KPS & $M L$ & MP \\
Kepuasan Pelajar & & 1.639 \\
Mass Lecture & 0.162 & \\
Motivasi Pelajar & 0.178 & \\
\hline
\end{tabular}

Keputusan $\mathrm{f}^{2}$ (Effect Size) 


\section{Keputusan $\mathbf{Q}^{2}$ (Predictive Relevance)}

Pengujian predictive relevance dilakukan menggunakan kaedah blindfolding. Jadual 14 menunjukkan nilai $\mathrm{Q}^{2}$ bagi model kajian. Hasil analisa menunjukkan bahawa nilai $\mathrm{Q}^{2}$ bagi konstruk mass lecture adalah 0.452 dan motivasi adalah 0.429 . Kesemua nilai yang dicatatkan adalah melebihi nilai sifar, bermakna bahawa model ini mempunyai predictive relevance yang mencukupi dan relevan untuk konstruk endogenues.

Jadual 14: Nilai $Q^{2}$ pada Konstruk Bersandar

\begin{tabular}{lc}
\hline Konstruk Bersandar & $\mathbf{Q}^{\mathbf{2}}$ \\
\hline Kepuasan Pelajar & 0.452 \\
Mass Lecture & 0.429 \\
Motivasi Pelajar &
\end{tabular}

\section{Analisis Pemboleh Ubah Mediator (Diriect-Indirect Effect)}

Jadual 15 menunjukkan hubungan antara mass lecture dan kepuasan pelajar dengan adanya motivasi pelajar sebagai mediator. Dapatan menunjukkan nilai indirect effect adalah 0.334 bersamaan $33.4 \%$ dan nilai $\mathrm{P}$ adalah 0.000 . Bererti wujudnya hubungan mediator yang positif dan signifikan dalam model kajian. Ini membuktikan bahawa hubungan yang berlaku antara mass lecture dan kepuasan pelajar boleh juga disebabkan oleh pemboleh ubah mediator.

\section{Jadual 15: Analisa Indirect Effect}

\begin{tabular}{lcl}
\multicolumn{1}{c}{ Hubungan } & Specific Indirect Effects & Nilai P \\
\hline Mass Lecture $->$ Motivasi Pelajar $->$ Kepuasan Pelajar & 0.334 & 0.000 \\
\hline Indirect Effact
\end{tabular}

Rajah 16 menunjukkan nilai direct effect bagi semua pemboleh ubah, didapati bahawa pemboleh ubah mediator dalam kajian ini adalah bersifat mediator separa kepada endogenenous. Ini kerana nilai pemboleh ubah mass lecture kepada kepuasan pelajar adalah tinggi iaitu 0.740 dan nilai motivasi kepada kepuasan adalah 0.424 .

Jadual 16: Analisa Direct Effect

\begin{tabular}{lcc}
\multicolumn{1}{c}{ Hubungan } & Direct Effect & Nilai P \\
\hline Mass Lecture -> Kepuasan Pelajar & 0.740 & 0.000 \\
Mass Lecture -> Motivasi Pelajar & 0.788 & 0.000 \\
Motivasi Pelajar -> Kepuasan Pelajar & 0.424 & 0.000 \\
\hline DirectEffect
\end{tabular}

\section{Dapatan Bootstrapping}

Rajah 3 menunjukkan keputusan evaluasi path coefficient yang digunakan untuk menunjukkan berapakah kekuatan pengaruh variabel tidak bersandar kepada variabel bersandar setelah semua pengujian di atas dilakukan. Berdasarkan rajah 3 diatas juga, seluruh variable memiliki path coefficient dengan angka positif, ini bererti semakin besar nilai path coefficient maka semakin kuat pengaruh pemboleh ubah bebas terhadap pemboleh ubah tidak bebas. 


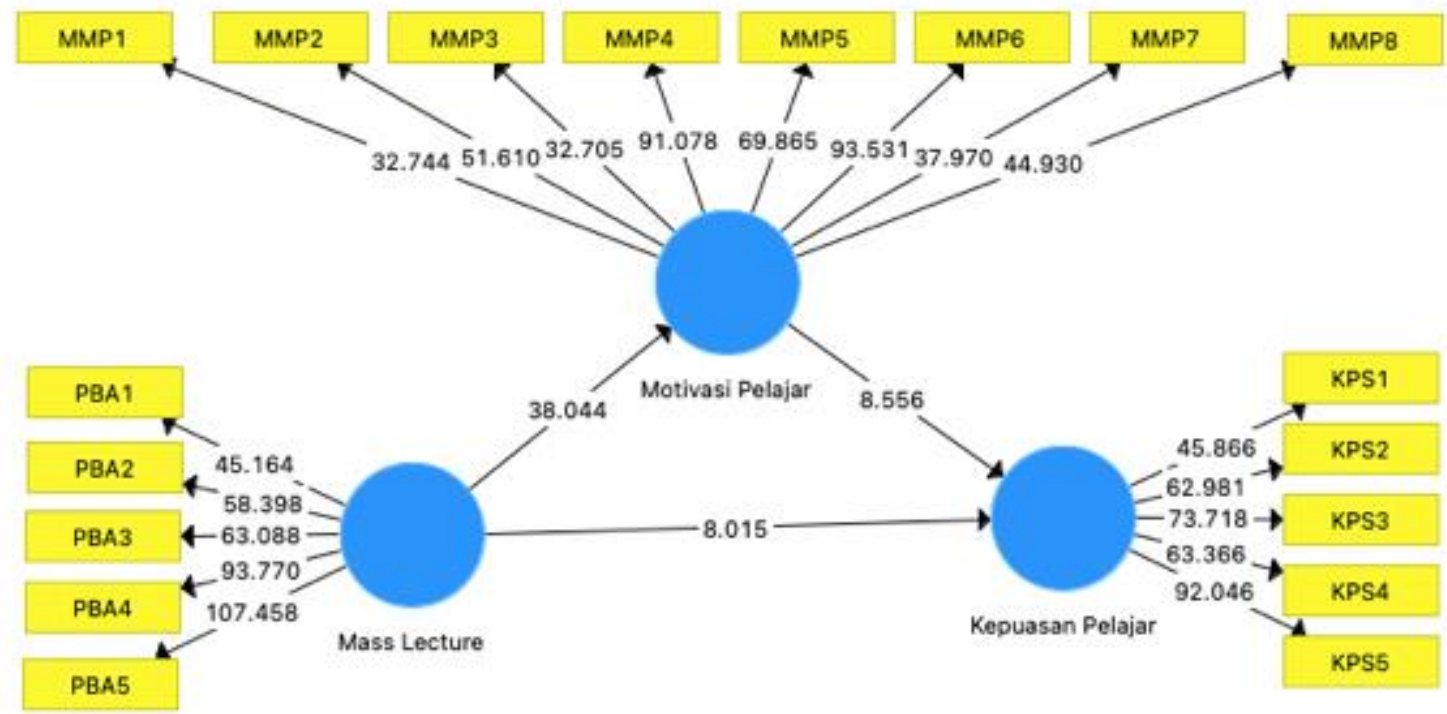

\section{Dapatan Ujian Hipotesis}

Seterusnya dibentangkan dapatan pengujian hipotesis dengan membandingkan nilai $p$-value dan nilai alpha 0.05 dengan pengiraan $0.05<p$-value sama ada hipotesis diterima dan signifikan atau ditolak. Manakala (ß) samada negatif atau positif. Atau dilihat pada t-value > 1.96 juga dikira signifikan. Hasil ujian menunjukkan semua hipotesis diterima, terbukti bahawa $\mathrm{H}_{1} \mathrm{H}_{2}, \mathrm{H}_{3}$, dan $\mathrm{H}_{4}$ berpengaruh positif dan signifikan.

Jadual 17: Analisa Path Coefficients (PC)

\begin{tabular}{lcccccc}
\hline \multicolumn{1}{c}{ Hubungan } & H & $(\mathbf{B})$ & SE & t & P & Keputusan \\
\hline Mass Lecture -> Kepuasan Pelajar & $\mathrm{H}_{1}$ & 0.406 & 0.051 & 8.015 & 0.000 & $\begin{array}{c}\text { Positif } \\
\text { Signifikan }\end{array}$ \\
Mass Lecture -> Motivasi Pelajar & $\mathrm{H}_{2}$ & 0.788 & 0.021 & 38.044 & 0.000 & $\begin{array}{c}\text { Positif } \\
\text { Signifikan } \\
\text { Positif }\end{array}$ \\
$\begin{array}{l}\text { Motivasi Pelajar -> Kepuasan Pelajar } \\
\begin{array}{l}\text { Mass Lecture -> Motivasi Pelajar -> Kepuasan } \\
\text { Pelajar }\end{array}\end{array} \mathrm{H}_{3}$ & 0.424 & 0.050 & 8.556 & 0.000 & $\begin{array}{c}\text { Signifikan } \\
\text { Positif }\end{array}$ \\
\hline
\end{tabular}

Path Coefficients

\section{H1: Terdapat pengaruh Mass Lecture (ML) terhadap Kepuasan Pelajar (KPS).}

Berdasarkan jadual 17, menjelaskan nilai jalur koefisien pada (Original Sample) ML terhadap KPS adalah 0.406 , iaitu bernilai positif. Nilai $\mathrm{P}=0.000<$ dari nilai tingkat signifikan 0.05 , maka ML berpengaruh positif dan signifikan terhadap KPS. Manakala nilai T-Statistics 8.015 iaitu > 1.96, bermaksud $\mathrm{H}_{1}$ adalah merupakan hipotesis yang diterima. Kesimpulannya, mass lecture berpengaruh positif dan signifikan terhadap kepuasan pelajar.

\section{H2: Terdapat pengaruh Mass Lecture (ML) terhadap Motivasi Pelajar (MP)}

Berdasarkan jadual 17, menjelaskan nilai jalur koefisien pada (Original Sample) ML terhadap MP adalah 0.788 , iaitu bernilai positif. Nilai $\mathrm{P}=0.000<$ dari nilai tingkat signifikan 0.05 . Manakala nilai 
T-Statistics 38.044 iaitu > 1.96, bermaksud $\mathrm{H}_{2}$ adalah merupakan hipotesis yang diterima. Dapatan membuktikan bahawa mass lecture berpengaruh positif dan signifikan terhadap kepuasan pelajar.

\section{H3: Terdapat pengaruh Motivasi Pelajar (MP) terhadap Kepuasan Pelajar (KPS)}

Berdasarkan jadual 17, menjelaskan nilai jalur koefisien pada (Original Sample) MP terhadap KPS adalah 0.424 , iaitu bernilai positif. Nilai $\mathrm{P}=0.000<$ dari nilai tingkat signifikan 0.05 . Manakala nilai T-Statistics 8.556 iaitu $>1.96$, bermaksud $\mathrm{H}_{3}$ adalah merupakan hipotesis yang diterima. Hasil kajian menunjukkan bahawa motivasi pelajar berpengaruh positif dan signifikan terhadap kepuasan pelajar.

\section{H4: Motivasi Pelajar memediasi pengaruh persepsi Mass Lecture terhadap Kepuasan Pelajar (KPS)}

Berdasarkan jadual 17, menjelaskan nilai jalur koefisien pada (Original Sample) MP sebagai mediator antara mass lecture dan KPS adalah 0.334 , iaitu bernilai positif. Nilai $\mathrm{P}=0.000<$ dari nilai tingkat signifikan 0.05. Manakala nilai T-Statistics 8.668 iaitu $>1.96$, bermaksud $\mathrm{H}_{4}$ adalah merupakan hipotesis yang diterima. Dapatan kajian membuktikan bahawa motivasi pelajar berpengaruh positif dan signifikan memediasi persepsi mass lecture terhadap kepuasan pelajar.

\section{Perbincangan Kajian}

Pembelajaran Bahasa Arab secara ML menunjukkan nilai beta 0.406 . Nilai P Values $=0.000<$ dari nilai tingkat signifikan 0.05. Manakala nilai T-Statistics 8.015 iaitu > 1.96, maka mass lecture berpengaruh positif dan signifikan terhadap kepuasan pelajar. Manakala nilai jalur koefisien pada (Original Sample) ML terhadap MP adalah 0.788, iaitu bernilai positif. Hal ini bererti mass lecture berpengaruh positif terhadap motivasi pelajar. Nilai $\mathrm{P}=0.000<$ dari nilai tingkat signifikan 0.05 . Manakala nilai T-Statistics 38.044 iaitu > 1.96. Dapatan membuktikan bahawa mass lecture dan motivasi berpengaruh positif dan signifikan terhadap kepuasan pelajar.

Pada rajah 3, menunjukkan nilai guru mahir menyediakan dan memberi setiap aktiviti latihan dan pentaksiran yang membantu pemerolehan bahasa adalah sebanyak 93.77, manakala pendekatan pengajaran bahasa Arab yang dipraktikkan secara sistematik oleh pensyarah sepanjang mass lecture mempunyai nilai path coefficient yang tertinggi iaitu sebanyak 107.458. Selain itu, pembelajaran segerak bersama pensyarah dan bilangan pentaksiran yang tidak membebankan pelajar serta sesuai dengan masa pembelajaran, menjadi antara sebab pembelajaran bahasa Arab secara mass lecture adalah signifikan terhadap kepuasan pembelajaran bahasa. Dapatan kajian ini secara langsung mengukuhkan beberapa teori pembelajaran bahasa seperti teori kognitif yang mementingkan guru mahir dan memahami tahap dan mod pelajar. Menurut teori kognitif, guru hendaklah memberikan aktiviti yang selaras dan sepadan dengan situasi dan kognitif pelajar (Wardsworth, 1990). Dalam konteks kajian ini, peranan guru yang memahami mod pelajar ketika menyediakan latihan, pentaksiran dan bahan pengajaran yang bersesuaian dengan konteks mereka diamalkan, maka pengamalan ini jelas terbukti dapat meningkatkan motivasi mereka. Usaha ini juga telah menjadi salah satu faktor kepada pelajar mendapat kepuasan dalam pembelajaran mereka.

Dapatan analisis Importance and Performance Matrix (IPMA) menunjukkan mass lecture merupakan pemboleh ubah bagi kepuasan yang mencatatkan kepentingan paling tinggi dengan nilai 84.42 , dan nilai prestasi sebanyak 80.76. Dapatan membuktikan bahawa walaupun mass lecture dan motivasi mencatatkan prestasi yang hampir sama dalam memberi kepuasan pembelajaran untuk pelajar, tetapi motivasi mencatatkan kepentingan yang rendah iaitu 48.60. Oleh itu, motivasi dalam proses pengajaran dan pembelajaran hendaklah diberi penekanan sewajarnya supaya dapat meningkatkan lagi kepuasan dalam pembelajaran.

Motivasi Pelajar (MP) dengan nilai beta 0.424 berpengaruh positif terhadap kepuasan pelajar. Terdapat pengaruh mass lecture terhadap motivasi adalah tinggi iaitu sebanyak $78.8 \%$. Motivasi pelajar berpengaruh positif dan signifikan terhadap kepuasan pelajar. Berdasarkan pemerhatian dari 
pengamalan mass lecture, pelajar bermotivasi menyiapkan tugasan yang diberikan, antara sebab peningkatan motivasi pelajar dalam kelas bahasa Arab secara mass lecture ialah bahan pengajaran bahasa Arab sendiri iaitu dengan nilai path coefficient pada rajah 3 adalah 91.0 dan metod pengajaran dalam pelaksanaan mass lecture dengan nilai path coefficient adalah 93.53 (rajah 3). Oleh yang demikian, hasil kajian menunjukan dapatan yang selari dengan Diah (et. al.,2020) iaitu 70\% pelajar bersetuju bahawa motivasi berpengaruh terhadap kepuasan pembelajaran, ditambah dengan faktor dorongan daripada guru mahir yang berdisiplin, dapat meningkatkan motivasi pembelajaran pelajar. Ia juga mengukuhkan pandangan Slavin (2000) yang menyatakan bahawa penyampaian pengajaran yang terperinci, menggunakan kaedah dan pengukuhan yang positif serta bersistematik dapat meningkatkan minat dan motivasi pelajar. Dapatan juga mengukuhkan pandangan teori pembelajaran humanis yang berpendapat bahawa pembelajaran bahasa itu bergantung kepada emosi dan perasaannya (Raskin 2005).

\section{Kesimpulan}

Pelaksanaan kuliah pembelajaran bahasa Arab secara Pendekatan Mass Lecture atau pengajaran dalam skala yang besar mungkin dapat menjadi salah satu cara penyelesaian yang sesuai ketika menghadapi masalah kekurangan tenaga kerja, atau apabila sesebuah institusi pengajian ingin melaksanakan penjimatan kos pembayaran tenaga pengajarnya. Namun, perlaksanaannya perlu ditangani dengan bijaksana supaya tujuan sebenar pembelajaran bahasa akan tercapai sepanjang tempoh perlaksanaannya.

Kajian ini mendapati bahawa faktor motivasi pelajar berpengaruh positif dan signifikan terhadap kepuasan pelajar. Mass lecture Bahasa Arab berpengaruh positif dan signifikan terhadap kepuasan pembelajaran pelajar. Motivasi berpengaruh positif dan signifikan terhadap kepuasan pembelajaran pelajar. Motivasi berpengaruh positif dan signifikan memediasi persepsi mass lecture terhadap kepuasan pembelajaran pelajar.

Kajian ini juga dapat menjelaskan hubungan yang penting antara kaedah pengajaran mass lecture dan motivasi. Dalam mass lecture, guru bahasa yang mahir terutama dalam situasi kini yang menuntut pengajaran dan pembelajaran berlaku secara online amat diperlukan. Guru yang mahir bukan sahaja berkemahiran dalam pengajaran, malah pada masa yang sama mereka seharusnya mahir dan peka dengan situasi dan konteks pelajar. Setiap latihan dan tugasan, pentaksiran, bahan-bahan pengajaran, dorongan dan bimbingan kepada pelajar hendaklah bersesuaian. Justeru, usaha ini memerlukan perancangan secara kolaboratif yang disusun rapi. Antara contoh persediaan yang boleh dilaksanakan secara kolaboratif ialah mewujudkan beberapa kumpulan di kalangan guru seperti kumpulan penyediaan bahan pengajaran, kumpulan penyediaan latihan, kumpulan penyediaan video pengajaran, kumpulan penyediaan nota tambahan, kumpulan pentaksiran dan kumpulan penyampaian syarahan secara mass lecture. Perlu diambil perhatian, gerak kerja secara berkumpulan ini perlu dilakukan empat atau lima bulan sebelum pengajaran mass lecture dilaksanakan di peringkat institusi.

Sehubungan itu, pemantauan dan penambahbaikan perlu dilakukan secara berterusan seperti memastikan setiap kali kuliah syarahan mass lecture dijalankan maka direkodkan secara video. Videovideo ini akan disebarkan kepada semua pelajar, ia bertujuan untuk memudahkan mereka mengulang kaji sendiri pelajaran mereka di rumah. Dalam pembelajaran mass lecture, latihan dan pentaksiran tidak boleh terlalu banyak dan berat. Bahan bantuan pengajaran berbentuk video yang di upload di Youtube adalah merupakan yang paling sesuai dan mudah untuk pelajar akses pada masa kini. Apabila semua ini dapat dipenuhi, maka pembelajaran dan pengajaran secara mass lecture dijangka akan dapat meningkatkan motivasi dan memberi kepuasan kepada pelajar. Kaedah mass lecture juga boleh menjadi norma baru dalam pengajaran dan pembelajaran Bahasa Arab Komunikasi pada masa hadapan. 


\section{Rujukan}

Abdul Hakim Abdullah, Ab Aziz Sulaiman \& Wan Ismail Wan Abdullah. (2015). Faktor-faktor yang mempengaruhi motivasi terhadap pembelajaran bahasa Arab. Jurnal Islam dan Masyarakat Kontemporari, 10(2), 104-121. Diambil dari https://bit.ly/3kZyD8M

Abdullah, N. H., Laily Ramli, N. H., \& Rafek, M. (2017). Mass lecture in language learning: What do the boys and girls think?. Journal of Advances in Humanities and Social Sciences, 3(2), 115-123.

Aditya Kamajaya Putra \& Agus Frianto. (2018). Pengaruh Motivasi Intrinsik dan Motivasi Ekstrinsik Terhadap Kepuasan Kerja. Jurnal BISMA, 6(1): 59-66.

Aktan, F. (2010). The Effects of Learner Characteristics on Satisfaction in Distance Education.Published thesis. The Ohio State University. Diambil dari https://etd.ohiolink.edu/!etd.send file?accession=osu1281368302\&disposition=inline

Azizi Ahmad. (2018). Kelas Syarahan Kecil vs Kuliah Syarahan di Dewan Kampus UOLS Sinar Harian Kumpulan Media Karangkraf Berhad. Kampus UOLS. Diambil dari https://www.academia.edu/37016512/Di_antara_kelas_syarahan_kecil_dan_syarahan_di_dewan_ kuliah_2018_

Bandura, A. (1977). Social learning theory. Englewood Cliffs, NJ: Prentice Hall.

Bellante, D. M. (1986). A Summary Report on Student Performance in Mass Lecture Classes of Economics, Washington. Journal of Economic Education, 4(1).

Bowman, N. D., \& Mete, A. (2014). I see smart people!: Using Facebook to supplement cognitive and affective learning in the university mass lecture. The Internet and Higher Education, 23, 1-8. Diambil daripada DOI: 10.1016/j.iheduc.2014.05.003

Cardozo, R. (1965). An experimental study of customer effort, expectation and satisfaction. Journal of Marketing Research, 2(3), 244-249.DOI: 10.2307/315018

Dewa Gede Rat Dwiyana Putra. (2019). Peran Kepuasan Belajar dalam Mengukur Mutu Pembelajaran dan Hasil Belajar. Jurnal Penjamin Mutu, Lembaga Penjamin Mutu, 5(1), 2548-3110. Diambil dari http://ejournal.ihdn.ac.id/index.php/JPM

Diah Zakiah, \& Yuni Mariah. (2020). Pengaruh Pembelajaran Daring di Era Pandemi Covid-19 Terhadap Motivasi dan Kepuasan Belajar Taruna/i Jurusan Teknika STIP Jakarta. Prosiding Seminar Pelayaran dan Riset Terapan. Sekolah Tinggi Ilmu pelayaran Jakarta, 2(1), 2020. Diambil dari DOI: https://doi.org/10.36101/pcsa.v2i1.121age Header Logo

Eamon, M. (1998). School of Social Sciences and Asian Languages, Has the mass lecture still got a place in university teaching?. Curtin University of Technology. Diambil daripada https://litec.curtin.edu.au/events/conferences/tlf/tlf1998/murphy-a.html

Ekoto, C.E., \& Gaikwad, P. (2015). The Impact of Andragogy on Learning Satisfaction on Graduate Students. American Journal of Educational Research, 3(11), 1378-1386. DOI: 10.12691/education-3-11-6.

Fahrurrozi, A. (2015). Pembelajaran Bahasa Arab : Problematika Dan Solusinya. Arabiyat: Jurnal Pendidikan Bahasa Arab dan Kebahasaaraban, 2 (1)161-180. http://journal.uinjkt.ac.id/index.php/arabiyat/article/view/1137/1009

Farah Wazera Mohamed Jaafer Sadiq \& Mohammad Mujaheed Hassan. (2021) Konsep Kendiri dan Gaya Pembelajaran terhadap Motivasi Akademik dalam kalangan Mahasiswa. Malaysian Journal of Social Sciences and Humanities (MJSSH), 6(2), 75-105. https://doi.org/10.47405/mjssh.v6i2.683.

Hanifal Fauzy AH, Zainal Abidin Arief, \& Muhyani. (2017). Impak Minat dan Motivasi Belajar Terhadap Hasil Belajar Siswa. Jurnal Pendidikan Islam, Universiti Ibn Khaldun, Bogor, Indonesia, 12(1), 112-127. DOI: 10.32832/tawazun.v12i1.1843

Ko, W.H., Chung, F.M. (2014). Teaching Quality, Learning Satisfaction, and Academic Performance among Hospitality Students in Taiwan. World Journal of Education, 4(5), 11-20.DOI:10.5430/wje.v4n5p11

Lam, B.H. (2007). Linking theory to practice: Active learning in mass lecture and tutorial. In B.-H. Lam, K.-T. Tsui, \& K.-F. S. Hui, Reflections on applying mass lecture plus tutorial approach in teacher training programme in Hong Kong (pp. 35-50). Hong Kong: The Hong Kong Institute of Education. 
Mohd Syuhaidi Abu Bakar \& Norsyahirah Ngah@Muhammad. (2018). Tahap Motivasi dan Tanggapan Pembaca Matang Terhadap Naskhah Terbitan Buku Fixi. e-Academia Journal 7(2), 122-129.

Makino, Y. \& Leppisaari, I. (2014). Dialogue Design System in a Mass Lecture Class: Bridging the Cultural Gaps in Pedagogy through Operation Videos. In J. Viteli \& M. Leikomaa (Eds.), Proceedings of EdMedia 2014--World Conference on Educational Media and Technology . Tampere, Finland: Association for the Advancement of Computing in Education (AACE). hlm.1361-1370. Diambil daripada https://www.learntechlib.org/primary/p/147662/.

Mohammad Haafiz Ahmid, Mohd Khairuddin Abdullah, \& Khalid Johari. (2018). Pengajaran Guru dan Kepercayaan Motivasi Pelajar dalam Pembelajaran Bahasa Arab di Sekolah Menengah. Malaysian Journal of Social Sciences and Humanities (MJSSH), 3(3), 136 -147.

Ni Putu Aprilia Krismony, Desak Putu Parmiti \& Gusti Ngurah Japa. (2020). Pengembangan Instrumen Penilaian untuk Mengukur Motivasi Belajar Siswa. Jurnal Ilmiah Pendidikan profesi Guru, 3(2), 249-257. http://dx.doi.org/10.23887/jippg.v3i2

Nor Sahayu Hamzah, Zaid Mohd Zin \& Mohd Abdul Ghafar Mohd Ghazali .(2019). The Influence of Motivation in Learning Japanese Language on Secondary School Students. International Journal of the Malay World and Civilisation 7(3), 41 - 50. https://doi.org/10.17576/jatma-2019-0703-05

Nor Hidayati Abdullah, Nur Hani Laily Ramli \& Mahfuzah Rafek. (2017). Mass lecture in language learning: What do the boys and girls think?. Journal of Advances in Humanities and Social Sciences JAHSS, 3(2), 115-123.

Nuraisyah Muhammad \& Faridah Mydin Kutty. (2021). Hubungan Antara Pembelajaran Regulasi Kendiri dan Motivasi Terhadap Pencapaian Akademik, Malaysian Journal of Social Sciences and Humanities (MJSSH), 6(9), 215 - 229. https://doi.org/10.47405/mjssh.v6i9.1006.

Rosmaza Sukardi, Harun Baharudin \& Maimun Aqsha Lubis. (2016). Konsep Gamification Sebagai Kaedah Meningkatkan Motivasi dalam Pembelajaran Bahasa Arab di Malaysia. Kolokium Pendidikan Bahasa Arab 2016 (KOLBAR 2016): hlm. 128-235.

Rais Hidayat \& Eka Suhardi. (2019). Instrumen Kepuasan Mahasiswa Universitas Swasta DenganMenggunakan Pemodelan Rasch. Jurnal Manajeman Pendidikan, 6(2), 169-178. https://ejournal.uksw.edu/kelola/article/view/2897/1350

Raskin, N. J., \& Rogers, C. R. (2005). Current psychotherapies . Person-centered therapy. In R. J. Corsini \& D. Wedding (Eds.), hlm. 130-165. Thomson Brooks/Cole Publishing Co.

Ricardo. (2017). Impak Minat dan Motivasi Belajar Terhadap Hasil Belajar Siswa. Jurnal Pendidikan, $1(1)$.

Lee, J.W., Soon Singh Bikar, Balan Rathakrishnan, \& Zulfikar Rabe. (2021). Integrasi Permainan Media Word Wall dalam Pendidikan Sejarah. Malaysian Journal of Social Sciences and Humanities (MJSSH), 6(4), 69 - 78. https://doi.org/https://doi.org/10.47405/mjssh.v6i4.765

Rosenfeld, L. B., \& Roy, M. B. (1990). Communicating with competency. Rhode Island, RI: Brown Higher Edu-cation

Rogers, C. (2011). Smartphone could replace wallets. News Straits Times November 26, 2011. Diambil daripada http://www.stuff.co.nz/technology/gadgets/6038621/Smartphone-could-replace-wallets

Savignon, S. J. (2002). Communicative Language Teaching: Context and Concerns in Teacher Education. New Haven. Yale University Press.

Siti Hajar Bidin, Hiyama Junko Abdullah, Nurul Sabrina Zan, Zulida Abdul Kadir, \& Rosmahalil Azrol Abdullah. (2019). Faktor sikap , motivasi dan jantina mempengaruhi penguasaan pembelajaran bahasa Jepun tahap 1 di Universiti Tun Hussein Onn Malaysia. Journal of Advanced Research in Social and Behavioural Sciences, 1(1), 105-115

Wadsworth, B. J. (1996). Piaget's theory of cognitive and affective development: Foundations of constructivism (5th ed.). Longman Publishing.

Wu, Y.C., Hsieh, L.F., Lu, J.J. (2015). What's The Relationship Between Learning Satisfaction and Continuing Learning Intention?. Article of WCES 2014. Procedia -Social and Behavioral Sciences 191(2015),2849 -2854.DOI: 10.1016/j.sbspro.2015.04.148

Zaliza Mohamad Nasira \& Zaitul Azma Zainon Hamzah (2014). Sikap dan Motivasi dalam Pembelajaran Bahasa Melayu. Journal of Social and Behavioral Sciences, 134, 408-415.

Zamri Chik, Abdul Hakim Abdullah, \& Habsah Muda. (2018). Peranan Faktor Demografik dalam Hubungan Antara Motivasi, Gaya Pembelajaran, Disiplin Pembelajaran dan Pencapaian Akademik Pelajar. Halaqa: Islamic Education Journal, 2(1), 101-116. 